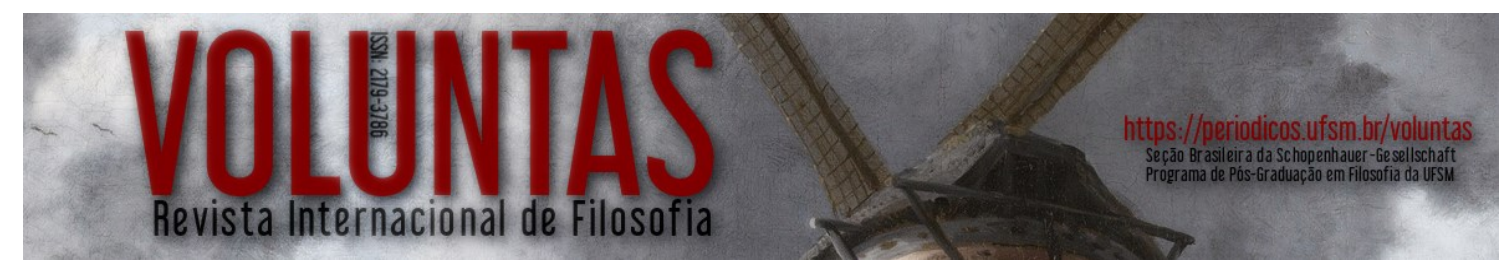

ISSN: 2179-3786

DOI: $10.5902 / 2179378633564$

\title{
EDITORIAL
}

\section{Um caminho filosófico com Schopenhauer}

\author{
A philosophical path with Schopenhaner
}

\author{
Maria Lúcia Cacciola \\ Professora da Universidade de São Paulo (USP) \\ Presidenta da Seção Brasileira da Schopenhauer-Gesellschaft \\ E-mail: $\underline{\text { mcacciola@uol.com.br }}$
}

$\mathrm{E}$ $m$ vez de apresentar uma análise conceitual da filosofia de Schopenhauer ou de algum conceito de sua filosofia e do seu filosofar, permito-me, desta vez, relatar minha experiência pessoal no campo da Filosofia, sobretudo a partir da filosofia desse autor, ligada a eventos pessoais acontecidos no campo da vida política brasileira, numa costura frouxa, contingente, sem relações de causa e efeito entre esses âmbitos.

A epígrafe deste "relato" meio novelesco, meio político, será o que Schopenhauer disse a Gwinner numa visita que recebeu deste último em setembro de 1860, alguns dias antes de sua morte. Segundo Gwinner, Schopenhauer teria dito que o fato de que os vermes fossem em breve devorar o seu corpo não lhe era um pensamento aterrador; e que, em contrapartida, ele pensava com terror em como seu espírito seria destroçado nas mãos dos "professores de filosofia". Como um deles, deixo um pouco de lado minha interpretação, para também deixar tranquilo nosso autor em seu repouso, descrevendo um pouco como, em meio às circunstâncias, me ocupei de "filosofia", como aprendiz e, depois, como professora.

Destinada eu à carreira jurídica, tendo-a escolhido como profissão, para tornarme advogada, promotora ou juíza, busquei um curso de Pós-Graduação que me introduzisse na Teoria do Direito e na Teoria política, tendo me inscrito para um trabalho sobre Maquiavel na Faculdade de Direito da USP, as famosas Arcadas. Um dos meus mestres, o honorável Prof. Gofredo da Silva Teles, era um democrata e liberal. O outro, que desconhecia na época, Prof. Alfredo Buzaid, logo fez-se notar, não pelas aulas, às quais nem se dignou a comparecer, mas por ter sido um dos relatores do famigerado AI-5, instrumento empregado em 1968 pela ditadura para fechar o Congresso e retirar direitos do homem e do cidadão, instaurando o reino do 
arbítrio, que podemos chamar de "estado de guerra hobbesiano". Abandonei a PósGraduação de imediato, sem me despedir. Algum tempo depois, em 1970, entrei na Faculdade de Filosofia da mesma USP, onde, apesar do desfalque de importantes professores, aposentados compulsoriamente, como Giannotti e Bento Prado, encontrei um ambiente mais propício para a reflexão e a crítica com jovens professores recém chegados de Paris, onde foram bolsistas, como Marilena Chauí e Luis Roberto Salinas Fortes, o grande rousseauísta (várias vezes preso e torturado no período desses anos de chumbo) de quem me tornei amiga e que faleceu prematuramente. Os cursos eram censurados, Marx excluído, o perigo rondava e a vigilância era exercida pelos professores mais velhos como V. Knoll e Maria Silvia Carvalho Franco, vinda das Sociais, que tudo fizeram para defender nossa Faculdade das arbitrariedades do regime militar. No lugar de Marx, Nietzsche; cujo caráter disruptivo nos alertava contra as ilusões do discurso oficial. Assisti a pelo menos três cursos sobre Nietzsche, que também ocupava um lugar no pensamento de esquerda e de extrema esquerda na França de maio de 68, e nos equivalentes grupos italianos. Depois de formada, ofereci, como monitora, um curso sobre Nietzsche com o Prof. Salinas, o que me levou ao interlocutor predileto de Nietzsche, Schopenhauer. O Prof. Salinas, aliás, se interessou pelo filósofo de Frankfurt, repetindo: "ele é o Rousseau alemão". Não sei bem se em virtude de traços de caráter, do pessimismo histórico ou da pitié e demais virtudes "cristãs", assumidas por ambos.

Este introito, junto com as brilhantes aulas sobre a Doutrina da Ciência com o filósofo e poeta Rubens Rodrigues Torres Filho, me levou à carreira acadêmica. Tive a sorte e a honra de ter sido aceita como orientanda do Prof. Rubens cuja vasta cultura literária, filosófica e artística me "desasnaram" quase que definitivamente. Rubens era um espírito aberto, sempre pronto a ironias ásperas e, balanceando, brincadeiras ingênuas e, ao mesmo tempo, profundo rigor, que espalhava de maneira surpreendente, tanto nas suas aulas como na conversação. Cheio de espírito, esse orientador escreveu numa dedicatória a um dos exemplares de seus livros de poesia, depois dos meus anos de mestrado e doutorado: "que saudades de te desorientar". Lição que aprendi com ele para lidar com meus orientandos. Ele aceitou de imediato a ideia de orientar as teses que decidi fazer sobre Schopenhauer, apesar da inimizade deste com Fichte, seu autor - talvez - predileto. Escreveu um texto, que foi dedicado a mim, altamente crítico a Schopenhauer, empenhado em derrubar a acusação feita por ele a Kant, de que Kant teria se tornado mais dogmático na segunda edição da Crítica da razão pura, o que Schopenhauer atribuía ao temor de Frederico Guilherme II, um monarca obscurantista, que sucedeu o rei filósofo Frederico II, da época da Ilustração.

Defender alguém de dogmatismo nestes tempos sombrios da ditadura que fechava nossos horizontes era uma espécie de dever moral, de vontade de respirar um ar libertário, e de ver posto um termo à opressão. Este texto de Rubens me levou ao tema da minha tese "Schopenhauer e a questão do dogmatismo", inspirada neste texto 
do Rubens, e que não tinha como intuito defender Schopenhauer e atacar Kant, mas buscar as razões internas ao pensamento de Schopenhauer que o levavam a tal interpretação de Kant, para ele o grande gênio, isolado dos seus seguidores por distância infinita. Cito aqui Torres Filho, que no Prefácio ao livro de minha autoria exprime este objetivo de Schopenhauer: "Evitar e combater o dogmatismo era para ele também, como para todos os grandes mestres desse período, uma forma de assimilar a lição de Kant: tomar o mundo da representação por absolutamente real, eis o que conduz a "construir uma ontologia, onde só havia material para uma dianologia". Mas, ainda segundo Rubens, seu caso é, de todos, aquele em que fica mais claro o quanto esse "assimilar" conserva o sentido original de "tornar semelhante a si”; negar que a metafísica tenha uma vocação extramundana e procurar a explicação do mundo no próprio mundo". O que é, a seu ver, o reverso indissociável dessa operação de saneamento da filosofia"1.

Essa menção à orientação de Rubens Torres Filho e à pronta aceitação do tema tem sua razão no estudo do filósofo e mais geralmente da filosofia alemã no Departamento de Filosofia da USP. Nosso curso de feitio francês, dado aos "pais fundadores" de origem francesa, que foram chamados para formá-lo, era mais voltado para o estudo dos autores e dos comentadores da História da Filosofia. Com algumas exceções, é claro, principalmente os estudiosos de Marx, Hegel e Nietzsche e, no caso de Rubens, Fichte. Mas a filosofia alemã era vista pela ótica dos comentadores franceses em geral. Predominava Hegel na versão Hyppolite e outras. Schopenhauer havia contado naquele momento com pouca atenção dos franceses, que também pouco o conheciam, como eles próprios confessam. Isto pelo menos depois de um diálogo profícuo entre os intelectuais alemães e franceses, no entre guerras, como, por exemplo, atesta a Revue des Deux Mondes, em que há muitos artigos sobre Schopenhauer, e, aliás, onde se apresentam ao público europeu as primeiras aproximações entre Schopenhauer e a psicanálise, como no artigo de Pierre Janet. Ao mencionar como tema de tese Schopenhauer, um professor comentou: "Como? Vai estudar um filósofo menor, como se diz, de quinta categoria?" Rubens Torres, dada sua cabeça aberta e seu feitio de filósofo e artista era, pois, exceção e me encorajou nesta empreitada com muita maestria e até com uma certa nonchalance que lhe era característica, apesar do extremo rigor em seu trabalho. Outra exceção a essa idiossincrasia era o Prof. Lebrun, que nos ministrou cursos definitivos para nossa formação. Dialogava com Schopenhauer, principalmente a propósito de Kant. Kant era o carro chefe da filosofia alemã; em disciplina obrigatória, a famosa Moderna II, eu mesma ensinei Kant por mais de dez anos, num curso introdutório, inspirada também na lectio lebruniana, mas procurando sem dúvida discutir os chamados textos políticos e a Ilustração no seu contexto histórico. Também Paulo Arantes, que dominava a bibliografia francesa e alemã sobre Hegel, Marx, a Escola de

1 TORRES FILHO, R. R. Prefácio a Schopenhauer e a questão do dogmatismo, de M. L. Cacciola. São Paulo: Edusp, 1994. 
Frankfurt e inúmeros filósofos e comentadores, foi uma exceção num outro viés, pois ao se pôr criticamente em face do estruturalismo que tinha em vista o método e nem tanto o conteúdo, deu um curso sobre Schopenhauer que se chamava "A outra ideologia Alemã", numa linha talvez lukàcsiana. Aliás, foi ele quem, escrevendo sobre a filosofia no Brasil e, em especial, no Departamento paulistano, intitulou seu livro $O$ departamento francês de ultramar, não sem ácida ironia. Tudo se decidia na França? Ou melhor, na Europa?

O Departamento continuou tranquilamente sua tarefa de discutir os textos filosóficos clássicos, apresentados na vertente estrutural, moldada na França, na linha da História da Filosofia. E, assim, por anos em que lá desempenhei meu oficio, também segui de certo modo esse modelo, orientando muitas teses brilhantes sobre Kant, Schopenhauer e até Freud e Nietzsche, e procurando manter sempre o princípio de autonomia dos orientandos. Paralelamente a esse trabalho de História da Filosofia, tratava-se, não com menor relevo, de ética, de filosofia política, de lógica e de filosofia das ciências. Nesta época, as agências de fomento prosperando, os estudantes relativamente apoiados levavam adiante suas pesquisas, publicavam, reuniam-se com os professores em Colóquios setoriais e em Congressos de nível Internacional, como a ANPOF, e embora socialmente muito ainda estivesse por fazer, dada a precariedade dos estudos no Ensino Médio público (desmontado também pela ditadura) e a desigualdade entre os que podiam pagar cursinhos e entrar nas Universidade públicas, algumas exceções meritórias se impunham, deixando brechas que permitiam até mesmo o sucesso dos self made. As Universidades Federais e as Estaduais em geral cresciam, criavam seus próprios Programas de Pós-Graduação, fora do eixo Rio - São Paulo e os happy few se multiplicaram extraordinariamente.

No que nos diz respeito, a pesquisa schopenhaueriana ia de vento em popa, à contracorrente do pessimismo tão alardeado. Oito Colóquios Internacionais realizados, um Grupo Schopenhauer institucionalizado na ANPOF, teses, artigos. Mas como poderia perguntar Lukács, já não se estaria anunciando com a vitória desse pessimista, uma decadência por vir? No caso, não só da burguesia local, mas do povo em geral, mistificado pela mídia e pela web num processo de golpe virtual, por meio de uma caça às bruxas já previamente escolhidas por seus algozes para o miserável papel? Golpe branco e sujo, sem armas, quase sem resistência, pois o inimigo insidioso desta vez não estava uniformizado, nem armado. Convivia conosco "numa boa", gentil e afável, tendo mesmo participado do lado do povo nas lutas pregressas contra a ditadura de 64. Se travestia de amigo do povo, portador da moral e justiceiro, mostrando suas luvas limpas cobrindo mãos ensebadas.

O primeiro ataque foi ao poder democraticamente constituído, a que se seguiram medidas contra os direitos trabalhistas, a previdência, o achatamento salarial, deixando em paz a prosperidade das finanças e apostando tudo na privatização que traria lucro certo aos seus autores e futuro incerto ao país. Logo após, ou ao mesmo 
tempo, promovendo o desastre cultural, expresso na falta de verbas que fez os concursos de admissão de cargos docentes minguarem, a competição desenfreada se instaurar entre candidatos a bolsas de estudo e também entre os candidatos a empregos nas Universidades. Desolação cultural que tende a se alastrar, inclusive nas agências de pesquisa mais renomadas do país, entre elas a Fapesp, que foi acusada por um governador, segundo publicação na imprensa, de promover pesquisas inúteis e cujo repasse de verbas diminuiu consideravelmente, promovendo o retorno dos happy few.

Voltemos aliviados ao nosso filósofo e a um de seus temas prediletos: a filosofia universitária. Um dos motivos alegados de cunho histórico, num comentário à tradução feita por Marcio Suzuki e por mim ao seu texto profundamente crítico Sobre a filosofia universitária, que tanto desdém causava ao nosso filósofo, tinha por motivo, de algum modo, a situação de subserviência da filosofia alemã em relação ao Estado e, por sua vez, deste à Igreja, principalmente no que tratava do provimento de cargos: candidatos se apresentavam numa lista tríplice e quem dizia a última palavra eram as autoridades civis e, sobretudo, clericais. Isto não está na letra do texto de Schopenhauer, que condenava no geral os filósofos de profissão, mas poderia bem ter ajudado a criar o clima propício à sua recusa, pois poder, competição, tirar vantagem eram obra da injustiça, da vontade de uns passando por cima da de outros. Além disso, Schopenhauer exigia que a filosofia deixasse de ser serva da teologia, o que desde há cem anos já tinha sido a exigência de um Kant, nunca totalmente realizada. Não nos esqueçamos que o nosso filósofo pertencia a um tempo que decerto inaugurava o filósofo como funcionário, se pensarmos nos períodos anteriores. Kant foi professor, mas tinha a marca do gênio e até mesmo Nietzsche louvou-o por ter sido filósofo apesar de funcionário. E não nos esqueçamos também que Fichte, mesmo criticado duramente por Schopenhauer, afinal teve a seu favor o fato de ter perdido sua vênia legendi por acusação de ateísmo, mesmo que depois a tivesse recuperado.

"A que vem esta fala" (?), vocês devem estar perguntando. Estamos aqui neste Colóquio que já tem tudo para ser bem-sucedido pela perfeita organização de Antonio Edmilson Paschoal e Vilmar Debona e pelo apoio da Universidade Federal do Paraná, com a habilidade em proverem seus custos. Por que este blá-blá-blá pessimista? Simplesmente porque, ao olhar em redor, vejo o caráter de exceção, de café filosófico da Ilha Fiscal.

Mas para que o meu (ou nosso) pessimismo não se torne um quietismo, e que ainda se possa falar com Lütkehaus e seus companheiros e precursores de uma "esquerda schopenhaueriana", proponho que este Colóquio Internacional se torne uma manifestação contra as posturas retrógradas e reacionárias que afetam o exercício da cultura e que induzem vergonhosamente o povo a iludir-se, os estudantes a serem mal formados, prestando-se como peças de engrenagem a fingir que pensam, quando

Voluntas: Revista Internacional de Filosofia - periodicos.ufsm.br/voluntas - Santa Maria - Vol. 9, n. 1, jan.-jun. 2018, pp. 5-10 
nada conseguirão pensar a não ser abstrações e que, em consequência, não conseguirão agir porque enredados na trama dos que venceram.

Peço desculpas por ter me manifestado de modo tão particular e local num Colóquio filosófico Internacional. Os estrangeiros que me perdoem, mas creio que esse problema não é apenas comezinho e caseiro, mas atinge também outros países e a Europa em particular, para nem falar nos demais. Vide as grandes manifestações contra as ordonnances trabalhistas de Macron na França, e o prejuízo que parece lhe estar vindo com os ventos anti-Merkel e a política dos refugiados, soprando do além Reno. Globalização! Pois o Grande uno é o Capital, e assim o Mundo se tornou um só, embora esfacelado pela desigualdade.

Vou propor também uma espécie de resgate da opinião de Schopenhauer sobre nós, professores universitários, ao não admitirmos qualquer tipo de conciliação com o status quo, tal como acreditava Horkheimer que o filósofo de Frankfurt o fizera, ultrapassando Hegel por não ter conferido qualquer positividade às misérias do mundo, não permitindo sua absorção num Absoluto. 